DOI: http://dx.doi.org/10.33846/ghs5404

\title{
Hubungan Pola Asuh Orang Tua dengan Keterampilan Sosial Remaja di Kota Depok
}

\author{
Yona Camelia Sahalessy (koresponden) \\ (Poltekkes Kemenkes Maluku; yonasahalessy@gmail.com)
}

\begin{abstract}
ABSTRAK
Remaja adalah usia untuk mencari dan menemukan identitas diri oleh karena itu remaja dituntut menguasai keterampilan sosial dan memiliki kemampuan menyesuaikan diri dengan lingkungan disekitarnya. Pengaruh gaya hidup modern turut mempengaruhi interaksi remaja dengan kelompoknya termasuk perilaku sosial. Remaja yang memiliki keterampilan sosial yang kuat, terutama pada penanganan konflik, keintiman emosional, dan penggunaan perilaku pro-sosial, lebih mungkin untuk diterima oleh teman sebaya dan masyarakat. Namun jika remaja gagal dalam menguasai keterampilan sosial menyebabkan mereka sulit menyesuaikan diri dengan lingkungan sehingga dapat menimbulkan perasaan rendah diri, dikucilkan dari pergaulan, cenderung berperilaku kurang normatif seperti perilaku asosial maupun antisosial. Penelitian ini bertujuan mengetahui hubungan pola asuh orang tua dengan keterampilan sosial remaja di Kota Depok. Desain penelitian yang digunakan adalah desain cross sectional yaitu jenis penelitian yang mencari hubungan antara variabel bebas dan variabel terikat dengan melakukan pengukuran sesaat. Responden pada penelitian ini adalah 184 remaja. Teknik sampling menggunakan simple random sampling. Kriteria inklusi adalah remaja yang tinggal dengan orang tua kandung. Hasil penelitian ini menunjukkan tidak ada hubungan antara pla asuh orang tua dengan keterampilan sosial remaja di Kota Depok. Penelitian ini merekomendasikan untuk melihat faktor-faktor lainnya yang mempengaruhi keterampilan remaja dan mengembangkan model layanan kesehatan remaja yang sesuai.
\end{abstract}

Kata kunci: remaja; keterampilan sosial; pola asuh orang tua

\section{PENDAHULUAN}

Masa remaja adalah masa peralihan dari kanak-kanak menuju dewasa dimana individu mulai mengembangkan dan memperluas kehidupan sosialnya. Masa remaja dibagi menjadi tiga fase yaitu remaja awal 12-15 tahun, remaja pertengahan 15-16 tahun dan remaja akhir 17-19 tahun ${ }^{(1)}$. Mencari dan menemukan identitas diri dengan cara berinteraksi dengan lingkungan sosialnya, dapat menangani masalah yang muncul sebagai hasil interaksi dengan lingkungan sosial serta mampu menampilkan diri sesuai dengan aturan dan norma yang berlaku di lingkungan sosial manapun menjadi sebuah proses yang dilalui remaja awal ${ }^{(1)}$

Pengaruh gaya hidup modern turut mempengaruhi interaksi remaja dengan kelompoknya termasuk perilaku sosial. Salah satu manifestasi gaya hidup yang diminati remaja saat ini adalah kebiasaan nongkrong di kafe, Bagi sebagian orang yang tinggal di perkotaan kafe menjadi "tempat kedua", selain rumah, kafe sebagai tempat atau sarana untuk membangun kehidupan sosial, baik itu nongkrong, bergaul atau sekedar mengaktualisasikan gaya hidup termasuk pada remaja ${ }^{(2)}$ Trend gaya hidup modern, urbanisasi dan penggunaan teknologi informasi sebagai media sosial dan komunikasi membawa pengaruh tersendiri terhadap perubahan perilaku sosial di masyarakat termasuk remaja yang populasinya terus bertambah baik di dunia, Indonesia termasuk di Kota Depok Jawa Barat.

\section{METODE}

Pada penelitian ini desain yang digunakan adalah desain cross sectional, Responden pada penelitian ini adalah 184 remaja. Teknik sampling menggunakan simple random sampling. Analisis data univariat disajikan dalam frekuensi dan presentase untuk data karakteristik Remaja, rerata dan standar deviasi untuk data keterampilan sosial dan frekuansi dan presentase untuk data pola asuh.

\section{HASIL}

Berikut ini adalah penyajian hasil-hasil penelitian. 
Tabel 1. Distribusi karakteristik remaja berdasarkan umur, jenis kelamin, pendidikan orang tua, pekerjaan orang tua dan pendapatan orang tua di Kota Depok, November, 2017 ( $n=184$ )

\begin{tabular}{|l|c|c|}
\hline \multicolumn{1}{|c|}{ Karakteristik remaja } & Jumlah & Persentase \\
\hline Usia & & \\
Remaja awal (10-14 tahun) & 137 & 74,5 \\
Remaja pertengahan & 45 & 24,5 \\
(15-16 tahun) & & \\
Remaja akhir (17-19 tahun) & 2 & 1,1 \\
\hline Total & 184 & 100 \\
\hline Jenis kelamin & & \\
Laki-laki & 88 & 47,8 \\
Perempuan & 96 & 52,2 \\
\hline Total & 184 & 100 \\
\hline Kelompok Teman Sebaya & & \\
Ada & 184 & 100 \\
Tidak ada & 0 & 0 \\
\hline Total & 184 & 100 \\
\hline Pendidikan Orang Tua & 54 & \\
Rendah & 115 & 29,3 \\
Menengah & 15 & 62,5 \\
Tinggi & 184 & 8,2 \\
\hline Total & & 100 \\
\hline Pekerjaan orang tua & 1 & \\
Tidak bekerja & 90 & 48,9 \\
Petani/Pedagang/Buruh & 74 & 40,2 \\
PNS/TNI/POLRI & 19 & 10,3 \\
\hline Wirausaha & 184 & 100 \\
\hline Total & 83 & \\
\hline Pendapatan orang tua & 101 & 45,1 \\
Kurang dari Rp 3.297.489 & 184 & 54,9 \\
\hline Lebih dari Rp 3.297.489 & & 100 \\
\hline Total & \\
\hline
\end{tabular}

Tabel 2. Distribusi pola asuh orang tua di Kota Depok, November, 2017 ( $n=184)$

\begin{tabular}{|l|c|c|}
\hline \multicolumn{1}{|c|}{ Karakteristik Remaja } & Jumlah & persentase \\
\hline Pola Asuh Orang Tua & & \\
Permisif & 152 & 82,7 \\
Otoritarian & 4 & 2,2 \\
Otoritatif & 28 & 15,1 \\
\hline
\end{tabular}

Tabel 3. Distribusi keterampilan sosial remaja di Kota Depok, November, 2017 ( $n=184)$

\begin{tabular}{|c|c|c|c|c|}
\hline Karakteristik remaja & Mean & SD & Minimal-Maksimal & $95 \% \mathrm{Cl}$ \\
\hline Keterampilan sosial & 82,91 & 10,826 & $56-120$ & $81,34-84,39$ \\
\hline
\end{tabular}

Tabel 3 menggambarkan rerata keterampilan sosial remaja di Kota Depok sebesar 82,91 (95\% Cl: 81,34- 84,39), dengan standar deviasi 10,826. Nilai keterampilan sosial terendah 56 dan tertinggi 120. Dari hasil estimasi interval dapat disimpulkan bahwa $95 \%$ diyakini rata-rata keterampilan sosial remaja adalah 81,34- 84,39.

Tabel 4. Analisis hubungan pola asuh dengan keterampilan sosial remaja di Kota Depok, November, 2017 ( $n=184)$

\begin{tabular}{|c|c|c|c|c|c|}
\hline Keterampilan Sosial & Mean & SD & SE & p value & $\mathrm{n}$ \\
\hline Permisif & 82,84 & 11,082 & 0,899 & 0,833 & 152 \\
Otoritatif /Otoritarian & 83,28 & 9,669 & 1,709 & & 32 \\
\hline
\end{tabular}


Berdasarkan Tabel 4, hasil uji statistik didapatkan nilai $p=0,833$, berarti pada alpha $5 \%$ tidak terdapat perbedaan yang signifikan rata-rata keterampilan sosial remaja antara pola asuh permisif dengan pola asuh otoritatif.

\section{PEMBAHASAN}

Hasil analisis menunjukkan bahwa pendidkan ibu diketagorikan menjadi tiga yaitu pendidkan rendah, menengah dan tinggi. Kategori pendidikan menengah adalah yang paling tinggi dibandingkan dengan pendidikan rendah dan pendidikan tinggi. Pendidikan orang tua yang cukup memungkinkan untuk melakukan komunikasi yang terbuka dan baik dengan remaja sehingga meningkatkan kepercayaan diri mereka untuk beradaptasi dengan lingkungan sosial di lingkungan.(3) Pekerjaan orang tua responden yang paling banyak adalah petani/ pedagang/ buruh yaitu sebesar kemudian disusul oleh pekerjaan sebagai PNS/TNI/POLRI. Hal ini relevan dengan data statistik Kota Depok tahun 2016 tentang ketenagaan kerja yaitu, penduduk Kota Depok yang bekerja di sektor perdagangan dan jasajasa, manufaktur dan disektor pertanian. Orang tua responden memiliki pendapatan lebih yaitu diatas UMR Kota Depok. Penghasilan sering dikaitkan dengan status sosial ekonomi seseorang. Semakin tinggi penghasilan semakin baik status sosial ekonominya ${ }^{(4)}$ Penelitian ini menunjukkan mayoritas remaja mempersepsikan bahwa pola asuh yang dipakai oleh orang tua adalah tipe pola asuh permisif. Penelitian ini didukung oleh terhadap sejumlah siswa sekolah menengah pertama di Bayelsa State, Nigeria. Mayoritas responden mempersepsikan bahwa diantara ketiga gaya pola asuh yang berkontribusi terhadap kesejahteraan psikologis dan penyesuaian remaja di sekolah yang paling dominan adalah pola asuh permisif ${ }^{(5)}$

\section{KESIMPULAN}

Hasil penelitian ini menunjukkan tidak ada hubungan antara pla asuh orang tua dengan keterampilan sosial remaja di Kota Depok

\section{DAFTAR PUSTAKA}

1. Santrock, J.W, (2003) Perkembangan Remaja (edisi keenam), Terjemahan Jakarta: Penerbit Erlangga.

2. Fauzi, A., Punia, I. N., \& Kamajaya, G. (2017). Budaya Nongkrong Anak Muda Di Kafe (Tinjauan Gaya Hidup Anak Muda Di Kota Denpasar). Jurnal Ilmiah Sosiologi (Sorot), 1(1).

3. Yuldawati. (2008). Hubungan Antara Pola Asuh Orang Tua Dan Perilaku Seksual Pelajar SMA Negeri di Kota Solok. Tesis. Universitas Indonesia

4. Profil Kota Depok (2014). Portal Resmi Pemerintah Kota Depok www.depok.go.id/profil-kota diunduh pada 28 Maret 2017

5. Awoyemi, A. E., P., \& Dombo, D. O. (2016). Influence of parenting styles on psychological well-being and school adjustment of secondary school adolescents in bayelsa state, nigeria. Ife Psychologia, 24(2), 10-16. Retrieved from https://search. proquest.com/docview/1872196033?accountid=17242 